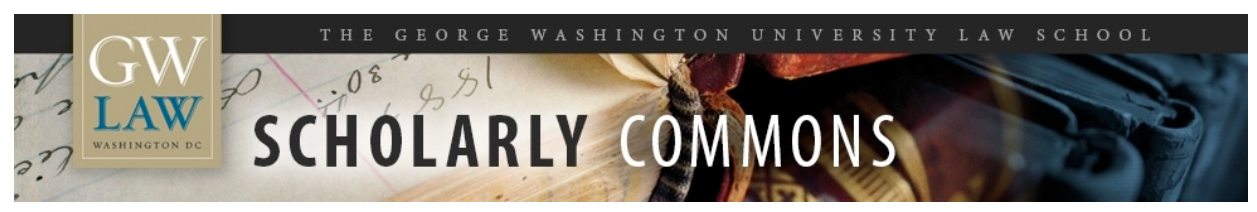

\title{
Chapter 4 from Margin of Trust: The Berkshire Business Model published by Columbia University Press
}

\author{
Lawrence A. Cunningham \\ George Washington University Law School, lacunningham@law.gwu.edu
}

Follow this and additional works at: https://scholarship.law.gwu.edu/faculty_publications

Part of the Law Commons

\section{Recommended Citation}

Cunningham, Lawrence A., Chapter 4 from Margin of Trust: The Berkshire Business Model published by Columbia University Press (December 2019). GWU Law School Public Law Research Paper No. 2019-72; GWU Legal Studies Research Paper No. 2019-72. Available at SSRN: https://ssrn.com/abstract=3502942

This Book Part is brought to you for free and open access by the Faculty Scholarship at Scholarly Commons. It has been accepted for inclusion in GW Law Faculty Publications \& Other Works by an authorized administrator of Scholarly Commons. For more information, please contact spagel@law.gwu.edu. 
Margin of Trust: The Berkshire Business Model

\author{
Lawrence A. Cunningham \\ George Washington University
}

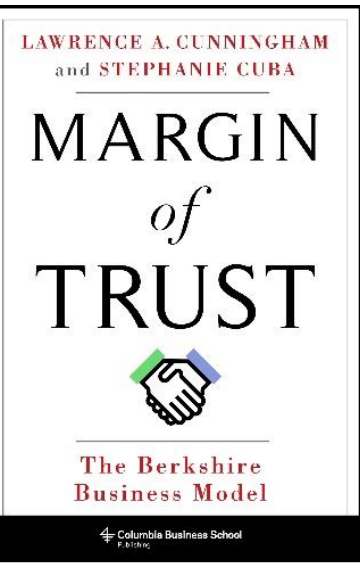




\section{Contents}

Prologue: The Carrot of Trust

Part I: Pillars

1. The Players

2. Partnership Practices

3. Business Methods

Part II: Perspectives

4. Deals

5. Boards

6. Internal Affairs

Part III: Alternatives

7. Contrasts

8. Comparisons

Part IV: Challenges

9. Judgment

10. Public Perception

11. Scale

12. Succession

Epilogue: The Stick of Ruthlessness 


\section{Deals}

In his wonderful book, Capitalism, Democracy and Ralph's Pretty Good Grocery, Ohio State University professor John Mueller stresses trust as an essential element in deal making. Trust enabled some of the most substantial deals in American industrial history:

People in American business rely on trust and reputation to make deals happen. For example, the agreements between Standard Oil and the railroads in the nineteenth century, of enormous economic consequence to both parties, were mostly sealed simply with a handshake. Indeed, if there is even a small chance that the courts would be required to make a deal work, the deal will probably not be consummated in the first place. [Where] trust has arduously, and profitably, been built up, efforts to further guarantee honesty by mechanical legalistic devices could actually be counterproductive. 1

Although most players in corporate America defer to the formality associated with legal contracts, bargains often go forward without them. Warren Buffett prefers the informal route, although elaborate formal agreements are unavoidable in many circumstances. Buffett's views and experiences with contracts, a subject almost never discussed in the thousands of books or articles on Buffett, offer insights into his profound preference for trust.

\section{Informal Promises}

Begin with two of the most famous of the many informal promises Buffett has made repeatedly since taking control of Berkshire in 1965 through to today. The first concerns his regular declaration that he regards Berkshire as a partnership, not a corporation, among all shareholders. This conception is the first of a dozen operating principles Berkshire publishes in its annual reports, dating to the mid-1980s, and has included in every one since 1995.

If there is a partnership, then Buffett and the rest of Berkshire's leadership owe owners 
far more stringent loyalty oaths than the fiduciary duties law puts on corporate directors. If taken at face value, Buffett's repeated statements suffice to form a partnership as a legal matter.

In context, they are aspirational statements of business philosophy to convey a conviction that shareholders are owners along with Buffett. No one has sued over this — and no such claim is imaginable given that Buffett and Berkshire's other leaders have undoubtedly met even the highest standards of partnership obligation.

With each passing year, as Buffett both repeats and honors this loyalty oath, the commitment strengthens while the deference he gets to deliver it widens. Such loyalty is an example of how to build a reservoir of goodwill through a business practice rather than a legal contract. It illustrates one of Muller's points noted in the quotation from Ralph's Pretty Good Grocery: "[Where] trust has arduously, and profitably, been built up, efforts to further guarantee honesty by mechanical legalistic devices could actually be counterproductive."

Second, for forty years, Buffett has repeatedly declared, in official Berkshire documents, presentations, and commentary, that when Berkshire acquires a company, it intends to hold it forever. And he has made good on that overture - retaining even companies that struggle financially. This is a claim on which sellers invariably place a great deal of trust in Buffett. Berkshire makes the specific point in acquisition discussions and it is often a basic rationale for many sellers to Berkshire, especially families and entrepreneurs, who value the commitment of permanence. But no such promises appear in the formal acquisition agreements Berkshire signs. That makes sense because an intention, backed by practice, is probably all that can realistically be given and provides the seller a sufficient basis to proceed.

Suppose, moreover, a seller requested Buffett or Berkshire to put the commitment in writing in a legally binding contract. Their signal could be construed as mistrust, which might doom the deal. To quote again from Ralph's Pretty Good Grocery: "if there is even a small chance that the courts would be required to make a deal work, the deal will probably not be consummated in the first place." 


\section{Acquisition Agreements}

In the past two decades, Berkshire acquired nearly twenty public companies. ${ }^{3}$ The deals are memorialized in highly formalized contracts, dictated by the practices of public companies. The common focus in these and all such acquisitions is on the seller's financial statements, which it represents to be fairly stated and on which any buyer relies.

These financial statement representations are elaborated in great detail. They explicitly reference arcane points: encompassing notes to the financial statements, schedules to securities law filings, the balance sheet, income statement, and cash flow statement—all as of specified dates or time periods; in accordance with a specific set of accounting standards, such as Generally Accepted Accounting Principles (GAAP), International Financial Reporting Standards (IFRS), or some other comprehensive basis of accounting; and subject to a separate schedule enumerating exceptions.

Lawyers and business people invest significant effort in delineating the financial statement representation to reduce any doubt about exactly what each side has agreed to. They try to leave no wiggle room for either side to later argue that the commitment was ambiguous or that some issues had not been decided. In effect, both sides aim to preclude the other from arguing, in court, that a judge should set aside the plain terms of the writing in favor of listening to testimony about the surrounding context.

Two of Berkshire's earliest acquisitions had very different financial statement warranties. Buffett has recounted these stories in the 2013 and 2014 shareholder letters, recalling deals that came to define Berkshire. At the time, they not only were critical acquisitions but also involved personal characteristics that warranted a different touch: one selling group was a family and the other was a friend of Buffett's.

The first example describes one of Berkshire's earliest and still historically most important acquisitions in terms of size - the 1967 purchase of National Indemnity Co. (NICO), today the world's largest property and casualty insurance company: 
[Insurance] has been the engine that has propelled our expansion since 1967, when we acquired National Indemnity and its sister company, National Fire \& Marine, for \$8.6 million. Though that purchase had monumental consequences for Berkshire, its execution was simplicity itself.

Jack Ringwalt, a friend of mine who was the controlling shareholder of the two companies, came to my office saying he would like to sell. Fifteen minutes later, we had a deal. Neither of Jack's companies had ever had an audit by a public accounting firm, and I didn't ask for one. My reasoning: (1) Jack was honest and (2) He was also a bit quirky and likely to walk away if the deal became at all complicated.

The purchase agreement we used to finalize the transaction was 1-1/2-pages long. That contract was homemade: Neither side used a lawyer. Per page, this has to be Berkshire's best deal: National Indemnity today has GAAP (generally accepted accounting principles) net worth of $\$ 111$ billion, which exceeds that of any other insurer in the world.

The second example describes one of Berkshire's earliest family-company acquisitions, which likewise was among the most important for establishing Berkshire's trust-based approach to its relationships - the 1983 purchase of Nebraska Furniture Mart (NFM), then owned by the Blumkin family:

I went to see Mrs. B (Rose Blumkin), carrying a 1-1/4-page purchase proposal for NFM that I had drafted. Mrs. B accepted my offer without changing a word, and we completed the deal without the involvement of investment bankers or lawyers (an experience that can only be described as heavenly). Though the company's financial statements were unaudited, I had no worries. Mrs. B simply told me what was what, and her word was good enough for me.

The circumstances of both NICO and NFM show extraordinary trust. Berkshire made these substantial acquisitions on informal terms. One of the central elements of such a deal, the financial statements, is accepted with a broad general statement of their veracity by an individual Buffett trusted. Yet, what would have happened had the financial statements turned out to be 
inaccurate or if Buffett's interpretation of the relevant accounting differed from that of either NICO or NFM?

In traditional formal contracts, financial statement representations provide rules to resolve such fights, such as that the statements are "fairly presented" or "comply with GAAP." But under these informal contracts, there are no such rules. Resolving any disagreement would require an understanding of the context of the business, the negotiations, and what each side understood about both.

Maybe Buffett simply assumed that he and both Ringwalt and Blumkin either would have had a shared understanding or would have been able to work out any difference. If they needed to turn to an impartial arbiter to decide, such as a court, the arbiter would need to gather a substantial amount of information beyond the limited guidelines included in the informal contracts.

The upshot is the enormous level of trust among these parties. If industrial America's most consequential formative deals were those between big oil and the railroads, Berkshire's were those with NICO and NFM. Those early purchases established Buffett and Berkshire's reputations as believers in trust. Buffett's decision to retell these stories from 1967 and 1983 in his letters of 2013 and 2014 affirms his continuing conviction to the value of trust.

\section{Best Efforts and Good Cause}

Many acquisitions require multiple agreements, such as both a formal merger agreement and separate employment contracts for key executives. One example concerned Berkshire's acquisition of the Scott Fetzer Company in 1986. Berkshire was a white knight amid hostile takeover overtures that put Scott Fetzer "in play."

The merger agreement was signed for Berkshire, and largely written, by Charlie Munger. ${ }^{4}$ It spanned just four pages when first executed and only eight pages upon being 
amended and restated in final form - about 20 percent the average length of merger agreements at the time.

Some provisions are common and straightforward. For example, among a few simple representations, the central one concerns financial statements and securities law filings. Likewise, one clause limited Scott Fetzer's rights to talk to other potential suitors who might be willing to pay more (a "no-talk" clause).

Then there were some novel provisions. For one, while state law required only a majority shareholder vote to approve the deal on the Scott Fetzer side, the contract called for a supermajority of two-thirds. In addition, the no-talk clause omitted any exception that would have allowed the board to talk to third parties if the board's fiduciary duty required it to do so. 5

On the contrary, the contract required Scott Fetzer's board to use its "best efforts" to close the Berkshire deal. This is a vague general concept whose meaning depends on context. To provide some context, however, this best efforts clause added a further novel and specific requirement: if the two-thirds vote were not received, Scott Fetzer would call another meeting the next quarter and "proceed with extraordinary diligence" to obtain the required votes. The contract then explains its purpose, another rare feature in typical merger agreements:

The purpose of the two-possible-stockholder-solicitations procedure is (i) to cause the first (and probably only) solicitation to be scheduled early to facilitate early payment of merger proceeds to Scott Fetzer shareholders and (ii) to assure that Parent, an extremely creditworthy and responsible corporation which is committed to the proposed merger with minimal contingencies, for the benefit of Scott Fetzer shareholders, will remain committed to the Merger for an extended period of time and will receive for its benefit in exchange for its commitment, a very thorough consideration of the terms of the proposed transaction by Scott Fetzer shareholders, the mutual commitments being deemed reasonable because the Agreement is submitted to an inherently demanding test of approval by twothirds of Scott Fetzer outstanding shares. 
The brevity, novelty, and clarity of this agreement are bracing. The approach distinguishes it from many others, and reflects a sophistication that would jump out at any judge interpreting the contract. The scope of most "best efforts" clauses would usually require attention to context, but the plain words accompanying this clause leave no mistake about what duty the parties wanted the board to have.

As written, the best efforts clause applied no matter what - even if corporate fiduciary duties might require the board to discuss a potentially better deal with other suitors. Courts have a hard time taking such clauses at face value and sometimes say fiduciaries cannot make a contract that eliminates their fiduciary duties. ${ }^{\mathbf{6}}$ Thus, a tension often exists between the contract's plain meaning and the deal's context.

In this case, the context is a white knight acquisition competing with at least one hostile bid that the Scott Fetzer board was determined to resist. Scott Fetzer and Berkshire both likely preferred the tightest possible clause. They seemed to have trusted each other very much, and mistrusted all other suitors intensely.

The Scott Fetzer acquisition agreement also called for Berkshire to honor the seller's existing senior executive employment agreements. On this point, Berkshire made a separate employment contract with the CEO, Ralph Schey, about which Buffett wrote in his chairman's letter to Berkshire shareholders a few years later:

Our compensation arrangement with Ralph Schey was worked out in about five minutes, immediately upon our purchase of Scott Fetzer and without the "help" of lawyers or compensation consultants. This arrangement embodies a few very simple ideas - not the kind of terms favored by consultants who cannot easily send a large bill unless they have established that you have a large problem (and one, of course, that requires an annual review).

Our agreement with Ralph has never been changed. It made sense to him and to me in 1986, and it makes sense now. Our compensation arrangements with the managers of all our other units are similarly simple, though the terms of each agreement vary to fit the economic characteristics of the business at issue, the 
existence in some cases of partial ownership of the unit by managers, etc.

In the Scott Fetzer transactions, we have two different kinds of agreements: a formal merger agreement (if an unusually short one) and an informal employment agreement (although one obviously containing key compensation terms). They are different for good reasons. The merger agreement serves a specific discrete and temporary one-off function-that is, the Scott Fetzer board getting the Scott Fetzer shareholders to approve the merger so that it can be closed and ownership can be acquired. A degree of trust is important, and the fewer provisions in the agreement the better. It is easy to zero in on exactly what's important without addressing anything else.

Unlike a merger agreement, an employment agreement addresses an ongoing working relationship of indefinite duration — it lasted fourteen years through Schey's retirement at seventy-five. Compensation and incentives are important, but it's hard to say what will matter most. When employment contracts specify an employee's duties, they usually contain broad general language, such as requiring the employee to exert his or her "best efforts" on the employer's behalf. Such a contract relies heavily on trust and the ability to determine the specific obligations it entails depends on context.

Berkshire usually carries over incumbent managers' contracts upon acquisition —and some are elaborate. Take that of David Sokol, head of MidAmerican Energy Company when Berkshire acquired it in 2000. The contract is fifteen single-spaced pages, with excruciating detail, including intricate treatment of termination.

Sokol was among Berkshire's most visible subsidiary CEOs and was widely seen as Buffett's successor. Yet, in 2014, he embroiled Berkshire in controversy by allegedly front running - that is, buying stock in a company before pitching it to Buffett as an acquisition target. The contract was pivotal because it restricted the company's termination right under a tight definition of "good cause."

The definition runs 425 words; subdefines legal concepts like "willful"; sets 
qualifications like gross misconduct and demonstrable injury; and requires advance warning of deficiencies and passage of a board resolution meeting stated criteria. For an executive in trouble, this provides strict plain parameters; a court need not even look up "willful" in a law dictionary.

But consider an executive who is in trouble under a vague contract, akin to how Buffett described the Schey deal. If the contract sets a term for a period of years, a legitimate reason ("good cause") would be needed to terminate. But exactly what that cause would be depends on both general legal definitions and the specifics of the contract.

Presumably front running would qualify, so Sokol would have been out under such a contract. After all, disappointed trust should be readily remedied. Under Sokol's actual contract, however, negotiated not by Berkshire but by the predecessor MidAmerican Energy, Berkshire's termination was more difficult. Sokol's lawyer even claimed the agreement permitted front running.

In the end, Berkshire followed the procedures and was able to terminate Sokol. The detailed contractual provisions required such corporate exertions, terms emanating not from a reservoir of trust but instead from mechanistic legalese. (We detail this episode further from additional perspectives in the epilogue.)

\section{The Spirit and the Letter}

At stake in the degree of formality or informality used to create and interpret contracts is what matters more, the letter or the spirit of agreement. On this issue, another pair of Berkshire contracts illustrates how an informal promise can be observed solemnly, whereas a formal one can be observed conditionally.

In each example, Berkshire acquired a public company with a family-held bloc concerned with aspects of history or operations: in 2000, the paint manufacturer Benjamin Moore \& Co., 
which had a longstanding commitment to an independent distributor model rather than big box retailers; and, in 2013, the condiment maker H. J. Heinz Company, which had an abiding loyalty to its hometown community of Pittsburgh.

One major difference marks these deals: Berkshire acquired all of Benjamin Moore, whereas Berkshire acquired Heinz in partnership with the private equity firm, 3G, which called most of the shots.

With Benjamin Moore, several contracts were signed, including a formal merger agreement and a shareholders' agreement committing Moore family members and other insiders to the transaction. All participants appreciated the centrality of the independent distributor system to the company as related public disclosure made plain.

The formal agreements contained no related promises. Shortly after closing, however, hearing concerns from distributors about continuity, Buffett made a video in which he expressly promised to maintain the system and not sell through big box retailers. Over ensuing years, when two successive CEOs at Moore signaled their willingness to break that promise out of business necessity, Buffett intervened to remove them, citing his commitment.

In Heinz, the merger agreement devoted an entire section to the company's cultural connection to Pittsburgh. It declared "that after the Closing, the Company's current headquarters in Pittsburgh, Pennsylvania will be the Surviving Corporation's headquarters."

A covenant, which survives the closing and is made by the acquisition subsidiary Berkshire jointly owned (called the "Parent"), promises: "after the Closing, Parent shall cause the Surviving Corporation to preserve the Company's heritage and continue to support philanthropic and charitable causes in Pittsburgh."

The contract referenced the company's contractual right to name Pittsburgh's professional athletic stadium, called Heinz Field, and required keeping that name. The contract required the parties to reference these commitments in their press releases about the deal.

But within a year of the Heinz deal, the company, led by managers appointed by 
Berkshire's coacquirer, 3G, cut three hundred jobs at it Pittsburgh headquarters. A further Pittsburgh dilution occurred soon thereafter, when Heinz merged with Chicago-based Kraft Foods Group to form the Kraft Heinz Company.

Although the company adopted dual headquarters and asserted it was keeping its Pittsburgh covenants, locals perceived a hollowing out and migration to Chicago. The actions may not have violated the covenants, but the reasonable questions stand in contrast to Moore. At Moore, a most informal promise was honored with spirited punctiliousness, whereas at Heinz, a highly formalized agreement was managed technically.

What of enforcement? In Moore, the circumstances might warrant letting the distributors enforce Buffett's promise. Amid known distributor centrality and concerns, express promises are made directly to distributors who, if induced to remain, would be entitled to enforce the promise. Although Buffett's exact words didn't actually make a corporate promise, such a major commitment to an independent distributor model would probably require approval of the company's board, not just the chief executive.

In Heinz, the language is less precise or ironclad than one might expect of a long-term corporate promise to maintain the company's connection to Pittsburgh. For instance, there's no time frame (just repeatedly saying "from and after Closing") or benchmarks (only vague references to "preserving heritage" and "supporting charities").

In addition, the Heinz promises are made by the buyer, which, upon closing, owns the seller and will not sue itself for breach. The agreement disclaims third-party enforcement rights other than stated exceptions, such as option holders and personnel covered by indemnification. There's no mention of, say, Pittsburgh headquarters' personnel, Pittsburgh charities, or the Heinz family. As a formal matter, it seems there is either no promise at all or, at best, a promise without a plaintiff.

But what about the circumstances? To Buffett, who believes in trust, the agreement memorializes a commitment - with imprecision that is understandable given the context. You 
might even say a conflict exists between the Pittsburgh promises and the no-third-party-rights clause, which would require more information to determine what was really intended by the clause. That conflict might suggest that the Pittsburgh promises were included only as a publicity stunt. If that seems deceptive, you could imagine letting the Pittsburgh interests have their day in court.

The Moore promise seems to be an avuncular assurance of intention rather than a contractual commitment—much like Buffett's vows of permanence, which he also uttered in the video. Likewise, the Heinz agreement may well involve an expression of "intent for the time being," statements of business conviction rather than legal covenant-much like Buffett's vows of Berkshire as a partnership. Ultimately, however, the Heinz contract and subsequent actions look more like a typical corporate approach to an acquisition than the more trust-animated Berkshire approach. The inclusion of $3 \mathrm{G}$ in the Heinz acquisition likely explains this difference. (This transaction, and private equity generally, are discussed further in chapter 7.)

A famous line appears in the annals of corporate acquisition agreements: "In Texas, a handshake is a contract." That argument persuaded a Texas jury in 1985 to find Texaco guilty of wrongfully disrupting a merger between Getty Oil and Pennzoil. The formal elaborate merger contract was never signed, but the jury's $\$ 10$ billion verdict sent Texaco into bankruptcy. ${ }^{7}$ Whether that is a good law or wise public policy, people do rely on informal promises to bind. This is a practice worth heeding, even when knowing that many legal details must be left for the formal printed agreement. It's also right to honor both the letter of the law and the spirit of the deal. 


\section{Notes}

1. John Mueller, Capitalism, Democracy and Ralph's Pretty Good Grocery (Princeton, NJ: Princeton University Press, 1999), 96.

2. See Lawrence A. Cunningham, Berkshire Beyond Buffett: The Enduring Value of Values (New York: Columbia University Press, 2014), 11: "During the mid-1980s, Berkshire would divest a few other failing businesses the Buffett Partnership had initially acquired — such as the department store chains Diversified Retailing, Associated Retail Stores, and Hochshild Kohn— but thereafter forswore doing so." It was then that Buffett discerned the economic value to sellers of Berkshire's promise of permanence. It was not until 2019 that Berkshire divested another subsidiary, in this case Applied Underwriters, a small specialty insurer whose sale was reportedly triggered by Berkshire's concurrent ownership of several rival companies operating in the same line. See Nicole Friedman, "Warren Buffett Is Doing Something Rare: Selling a Business," Wall Street Journal, February 27, 2019.

3 Benjamin Moore; BNSF; Clayton Homes; CTB; Dairy Queen; Fruit of the Loom; Garan; Gen Re; Johns Manville; Justin; Lubrizol; MidAmerican Energy; Precision Castparts; Shaw Industries; and XTRA. It also joined in the acquisition of Heinz, followed by its merger with Kraft.

4 We confirmed our hunch about Munger's drafting role by conferring with Robert Denham and Ronald Olson, two lawyers who were involved in the transaction and are still partners of the firm.

5 Such fiduciary "outs" did not become standard until shortly after this time. But even at this time, they were emerging with some frequency and taken seriously by courts, 
including in that year's landmark case, Smith v. Van Gorkom, 488 A.2d 858 (Del. 1985).

6 See Restatement (Second) of Contracts 193 (1981).

7 . See Thomas Petzinger Jr., Oil \& Honor: The Texaco-Pennzoil Wars (Washington, DC: Beard Books, 1987). 